\title{
Mind-body interventions for the treatment of insomnia: a review
}

\section{Intervenções mente-corpo para o tratamento de insônia: uma revisão}

\author{
Elisa Harumi Kozasa*, 1,2,3 Helena Hachul*, 1,4,5 Carlos Monson, ${ }^{6}$ Luciano Pinto Jr., ${ }^{1,4}$ Marcelo Csermak \\ Garcia, ${ }^{1,4}$ Luiz Eugênio de Araújo Moraes Mello, ${ }^{7}$ Sérgio Tufik ${ }^{1,4}$
}

\footnotetext{
1 Department of Psychobiology, Universidade Federal de São Paulo (UNIFESP), São Paulo, SP, Brazil

${ }^{2}$ Núcleo de Estudos em Saúde Coletiva e da Família, Universidade Nove de Julho, São Paulo, SP, Brazil

${ }^{3}$ Instituto do Cérebro, Instituto Israelita de Ensino e Pesquisa Albert Einstein, São Paulo, SP, Brazil

${ }^{4}$ Instituto do Sono, Universidade Federal de São Paulo (UNIFESP), São Paulo, SP, Brazil

${ }^{5}$ Department of Gynecology, Universidade Federal de São Paulo (UNIFESP), São Paulo, SP, Brazil

${ }^{6}$ Centro Cochrane do Brasil, Universidade Federal de São Paulo (UNIFESP), São Paulo, SP, Brazil

${ }^{7}$ Department of Physiology, Universidade Federal de São Paulo (UNIFESP), São Paulo, SP, Brazil

*Equal contribution
}

\begin{abstract}
Objective: As insomnia is highly prevalent, and side effects of medication are well-known, mind-body interventions are increasingly being sought. The objective of this study is to present a narrative review regarding the effects of mind-body interventions for the treatment of insomnia. Method: A PubMed search was conducted including only randomized, controlled trials in which the main objective was to treat insomnia. Discussion: Twelve studies were selected. In three of the studies, objective parameters (polysomnography) were analyzed. Mind-body interventions were able to improve sleep efficiency and total sleep time. Most can ameliorate sleep quality; some can reduce the use of hypnotic drugs in those who are dependent on these drugs. Conclusion: According to the studies we selected, self-reported sleep was improved by all mind-body treatments, among them yoga, relaxation, Tai Chi Chih and music. Cognitive behavioral therapy seems to be the most effective mind-body intervention. Cognitive behavioral therapy was the only intervention that showed better results than medication. However, considering that only five of the twelve studies chosen reached a score of 3 in the Jadad scale, new studies with a higher methodological quality have to be conducted especially in mind-body interventions that belong to the complementary or alternative medicine field.
\end{abstract}

Descriptors: Sleep; Cognitive therapy; Mind-body therapies; Psychotherapy; Evaluation of the efficacy-effectiveness of interventions
Resumo

Objetivo: Considerando-se que a insônia é altamente prevalente, e os efeitos colaterais das medicaçôes para seu tratamento são bem conhecidos, pesquisas no campo das intervençôes mente-corpo têm sido desenvolvidas. $O$ objetivo deste estudo é apresentar uma revisão narrativa sobre os efeitos das intervençôes mente-corpo para o tratamento de insônia. Método: Uma busca pelo site Pubmed foi conduzida incluindo-se apenas estudos controlados e randomizados nos quais o principal objetivo era o tratamento da insônia. Discussão: Doze estudos foram selecionados. Em três deles, parâmetros objetivos (polissonografia) foram analisados. Vários destes estudos mostraram melhora na qualidade do sono; em grupos de usuários de drogas hipnóticas ocorreu redução no uso das mesmas. Conclusão: De acordo com os estudos selecionados, todas as intervençôes mente-corpo melhoraram ao menos a qualidade subjetiva do sono, dentre elas yoga, Tai Chi Chih e música. A terapia comportamental cognitiva parece ser a mais efetiva destas intervençôes e foi a única que mostrou melhores resultados que a medicação. Porém, considerando que apenas cinco dos 12 estudos selecionados alcançaram o escore 3 na escala de Jadad, novos estudos com melhor qualidade metodológica precisam ser conduzidos especialmente dentre as intervençōes mente-corpo que estão no campo das práticas complementares ou alternativas.

Descritores: Sono; Terapia cognitiva; Terapia mente-corpo; Psicoterapia; Avaliação de eficácia-efetividade de intervençōes

(related to sleep quantity or quality), a symptom (part of a sleep disorder or of a mental or organic disorder) or a diagnosed

\section{Introduction}

Insomnia can mean different things depending on the clinical picture presented by the subject. Insomnia can be a complaint
Correspondence

Elisa Harumi Kozasa

R. Napoleão de Barros, 925

04024-002 São Paulo, SP, Brazil

Phone/Fax: (+55 11) 2149-0155

Email: ehkozasa@gmail.com 
sleep disorder (primary or secondary), indicating the need for a differential diagnosis process. Some epidemiological studies have attempted to define these distinctions. ${ }^{1-5}$ The DSM-IV describes the essential features of insomnia disorder as follows: a predominant complaint of insomnia that lasts for at least one month and that causes significant distress or daytime impairments in social, occupational or other sectors of daily life. . $^{1-3,6}$

Concerning sleep quality, $25.3 \%$ of the general population were dissatisfied with their sleep, 29.9\% reported insomnia symptoms and $9.5 \%$ met criteria for an insomnia syndrome. While few insomnia sufferers seek professional consultations, many individuals initiate self-help treatments, particularly when daytime impairments such as fatigue become more noticeable. ${ }^{7}$

Insomnia is associated with increased psychological symptomatology and perceived stress, higher predisposition to arousal and higher impairment of health quality. ${ }^{8}$ Insomnia has a close association with depression and anxiety.

Chronic insomnia affects approximately $9 \%$ to $12 \%$ of the population. ${ }^{4,10,11}$ Hypnotic drugs are generally prescribed to patients with insomnia. The frequency with which sleep medication is prescribed vary widely. ${ }^{12,13}$ Prescription rates of anxiolytic, hypnotic and sedative medications increased sharply over the last half decade, and zolpidem is increasingly prescribed for insomnia for the general population. Gender differences in prescription rates reflect the higher prevalence of anxiety and sleep disorders in women. The frequent use of these drugs in elderly people warrants further exploration because of the concomitant increased risks of mortality and morbidity. ${ }^{13}$

A meta-analysis of studies on sedative hypnotics (which typically include benzodiazepines) has shown that these drugs caused a number of side effects when used repeatedly for as little as a few weeks. Side effects included habituation, physical and psychological dependency, daytime psychomotor and cognitive impairment, daytime drowsiness or anxiety, iatrogenic sleep disturbance (involving suppression of slow-wave sleep and rapid eye movement (REM) sleep) and rebound insomnia upon the abrupt discontinuation of sedative hypnotic therapy. ${ }^{14}$

In addition, the use of non-pharmacological interventions has been increasing in the general population. According to a nationwide government survey, approximately $38 \%$ of U.S. adults aged 18 years and over and approximately $12 \%$ of children use some form of complementary or alternative medicine (CAM). CAM is a group of diverse medical and health care systems, practices and products that is not generally considered part of conventional medicine. Complementary medicine is used together with conventional medicine, while alternative medicine is used in place of conventional medicine. Integrative medicine combines conventional and CAM treatments for which there is evidence of safety and effectiveness. ${ }^{15}$

Mind-body interventions use a variety of techniques designed to enhance the mind's capacity to affect bodily function and symptoms. Some techniques that were considered CAM in the past have become part of the mainstream [for example, patient support groups and cognitive behavior therapy (CBT)]. Other mind-body techniques are still considered CAM, including meditation, prayer, mental healing and therapies that use creative outlets such as art, music or dance. ${ }^{16}$

It is hypothesized that mind-body interventions reduce sympathetic nervous system activity and increase parasympathetic nervous system activity, thereby restoring homeostasis in the balance of sympathetic/parasympathetic function. Mind-body techniques, including the relaxation response and cognitive restructuring, have been shown to be effective for the treatment of chronic insomnia. ${ }^{17}$ Mind-body interventions involving cognitive restructuring in the treatment of sleep maintenance in older adults with insomnia were more effective in the long term as compared to pharmacotherapy. The effects of pharmacotherapy were essentially limited to the period during which patients were taking the drug. ${ }^{18}$

Use of a mind-body intervention can be combined with pharmacotherapy in the treatment of insomnia. Studies examining the relative advantages of CBT and pharmacotherapy have found that improvements may be achieved more quickly with drug treatment; however, improvements are more sustained with CBT. Combining modes of treatment is not necessarily superior to monotherapy because long-term effects can vary between patients. Deciding which treatment to initiate first, or whether to run treatments concurrently, depends on factors such as the nature of the insomnia, treatment history, comorbid conditions, acceptability of treatment to the patient and treatment cost or availability. ${ }^{19}$

The objective of this study is to present a narrative review about the effects of mind-body interventions on the treatment of insomnia.

\section{Method}

A PubMed search was conducted by cross-referencing the terms ("mind-body" or "relaxation" or "mindfulness" or "yoga" or "tai chi" or "meditation" or "MBSR" or "prayer" or "mental healing" or "art" or "music" or "dance" or "hypnosis" or "biofeedback" or "imagery") and ("insomnia"). The search was limited to English language articles published between 2000 and 2009. We found 156 articles in this search and then selected randomized, controlled trials in which the main objective was to treat insomnia. Secondary insomnia was not considered in this review (for example, insomnia in cancer patients or insomnia related to alcoholism).

The instrument used in this review to assess the quality of randomized, controlled trials was the Jadad scale, which analyzes the adopted criteria of randomization, allocation concealment (blinding) and monitors losses and/or deletions occurred. ${ }^{20}$ The Jadad scale is a numerical scale ranging from 0 to 5 in which 0 indicates null methodological quality, 1 indicates very low methodological quality, 2 indicates low methodological quality, 3 indicates regular methodological quality, 4 indicates good methodological quality and 5 indicates very good methodological quality. 
Table 1 - Twelve articles which focus on the effects of mind-body interventions on the treatment of insomnia

\begin{tabular}{|c|c|c|c|c|}
\hline Authors & $\mathbf{N}$ & Subjects & Form of treatment & Main outcomes/Jadad scale score(JSS) \\
\hline $\begin{array}{l}\text { Vincent and } \\
\text { Lewycky } \\
(2009)^{21}\end{array}$ & 118 & $\begin{array}{l}\text { Adults with chronic } \\
\text { Insomnia }\end{array}$ & $\begin{array}{l}\text { Online treatment } \\
\text { (psychoeducation, sleep hygiene, } \\
\text { and stimulus control, etc.) or } \\
\text { waiting list * }\end{array}$ & $\begin{array}{l}\text { The treatment produced improvements in the } \\
\text { primary end points of sleep quality, insomnia } \\
\text { severity and daytime fatigue, dysfunctional } \\
\text { beliefs about sleep. JSS } 2 \text {. }\end{array}$ \\
\hline $\begin{array}{l}\text { Irwin et al. } \\
(2008)^{22}\end{array}$ & 112 & $\begin{array}{l}\text { Older adults with } \\
\text { moderate sleep } \\
\text { complaints }\end{array}$ & Tai Chi Chih ${ }^{\star \star}$ or health education & $\begin{array}{l}\text { Tai Chi Chih condition showed significant } \\
\text { improvements in the Pittsburgh Sleep Quality } \\
\text { Index (PSQI, habitual sleep efficiency, sleep } \\
\text { duration and sleep disturbance. JSS } 3 \text {. }\end{array}$ \\
\hline $\begin{array}{l}\text { Harmat et al. } \\
(2008)^{23}\end{array}$ & 94 & $\begin{array}{l}\text { Students with sleep } \\
\text { complaints }\end{array}$ & $\begin{array}{l}\text { Classical music, audiobook or no } \\
\text { intervention }\end{array}$ & $\begin{array}{l}\text { Music statistically significantly improved sleep } \\
\text { quality as measured by the PSQI and } \\
\text { depressive symptoms. Other groups did not } \\
\text { improve in these parameters. JSS } 2 \text {. }\end{array}$ \\
\hline $\begin{array}{l}\text { Soeffing et al. } \\
(2008)^{24}\end{array}$ & 47 & $\begin{array}{l}\text { Insomniac hypnotic- } \\
\text { dependent older } \\
\text { adults }\end{array}$ & $\begin{array}{l}\text { Cognitive-behavioral intervention- } \\
\text { CBI (relaxation, stimulus control or } \\
\text { sleep hygiene ) or placebo }\end{array}$ & $\begin{array}{l}\mathrm{CBI} \text { showed significant improvement compared } \\
\text { with placebo for: sleep onset latency, wake } \\
\text { time after sleep onset and sleep efficiency and } \\
\text { clinically meaningful improvement. JSS } 2 \text {. }\end{array}$ \\
\hline $\begin{array}{l}\text { Siverstien et al. } \\
(2006)^{25}\end{array}$ & 46 & $\begin{array}{l}\text { Older adults with } \\
\text { chronic primary } \\
\text { insomnia }\end{array}$ & $\begin{array}{l}\text { CBT (sleep hygiene, sleep } \\
\text { restriction, stimulus control, } \\
\text { cognitive therapy and relaxation), } \\
\text { 7.5-mg zopiclone each night or } \\
\text { placebo medication }\end{array}$ & $\begin{array}{l}\text { CBT group spent much more time in slow- } \\
\text { wave sleep and spent less time awake during } \\
\text { the night as compared with other groups. Total } \\
\text { sleep time was similar in all three groups; at six } \\
\text { months, patients receiving CBT had better } \\
\text { sleep efficiency than did those taking } \\
\text { zopiclone. JSS } 3 \text {. }\end{array}$ \\
\hline $\begin{array}{l}\text { Manjunath and } \\
\text { Telles } \\
(2005)^{26}\end{array}$ & 120 & Geriatric population & $\begin{array}{l}\text { Yoga, ayurvedic herbal } \\
\text { preparation or waiting list group }\end{array}$ & $\begin{array}{l}\text { The yoga group showed a significant decrease } \\
\text { in the time taken to fall asleep, an increase in } \\
\text { the total number of hours slept and in the } \\
\text { feeling of being rested in the morning after six } \\
\text { months. Other groups: no significant changes. } \\
\text { JSS } 2 \text {. }\end{array}$ \\
\hline $\begin{array}{l}\text { Morgan et al. } \\
(2004)^{27}\end{array}$ & 209 & $\begin{array}{l}\text { Long-term hypnotic } \\
\text { drug users }\end{array}$ & $\begin{array}{l}\text { CBT-treated sleep clinic group and } \\
\text { no additional treatment control } \\
\text { group }\end{array}$ & $\begin{array}{l}\text { CBT improves sleep quality, reduce hypnotic } \\
\text { drug use and health-related quality of life and } \\
\text { persists for at least one year among the more } \\
\text { treatment-adherent patients. JSS } 3 \text {. }\end{array}$ \\
\hline $\begin{array}{l}\text { Waters et al. } \\
(2003)^{28}\end{array}$ & 53 & Chronic insomnia & $\begin{array}{l}\text { Progressive relaxation + cognitive } \\
\text { distraction (PMR/CD), sleep } \\
\text { restriction + stimulus control } \\
\text { (SR/SC), flurazepam or a sleep } \\
\text { hygiene (SHE). }\end{array}$ & $\begin{array}{l}\text { Results indicated that PMR/CD had a greater } \\
\text { effect on sleep onset than did SR/SC and SHE. } \\
\text { SR/SC had a greater effect on sleep } \\
\text { maintenance than did PMR/CD, while MED } \\
\text { was better than the other treatments. JSS } 2 \text {. }\end{array}$ \\
\hline $\begin{array}{l}\text { Morgan et al. } \\
(2003)^{29}\end{array}$ & 209 & $\begin{array}{l}\text { Long-term hypnotic } \\
\text { drug users }\end{array}$ & $\begin{array}{l}\text { CBT-treated sleep clinic group or } \\
\text { no additional treatment control } \\
\text { group }\end{array}$ & $\begin{array}{l}\text { At follow-ups, long-term hypnotic users with } \\
\text { chronic sleep difficulties treated with CBT } \\
\text { reported significant reductions in sleep latency, } \\
\text { improvements in sleep efficiency and } \\
\text { reductions in the hypnotic drug use. JSS } 3 \text {. }\end{array}$ \\
\hline $\begin{array}{l}\text { Pallesen et al. } \\
(2003)^{30}\end{array}$ & 55 & $\begin{array}{l}\text { Older adults with } \\
\text { insomnia }\end{array}$ & $\begin{array}{l}\text { Sleep hygiene plus stimulus } \\
\text { control or sleep hygiene plus } \\
\text { relaxation tape (after a period of } \\
\text { non-intervention for half of the } \\
\text { sample). }\end{array}$ & $\begin{array}{l}\text { No significant changes were observed during } \\
\text { the waiting-list period. Effects of treatment } \\
\text { were greater for nocturnal measures as } \\
\text { compared to daytime measures and non- } \\
\text { targeted behavior (medication use). There } \\
\text { were no differences in treatment effects for the } \\
\text { two interventions. JSS } 2\end{array}$ \\
\hline $\begin{array}{l}\text { Edinger et al. } \\
(2001)^{31}\end{array}$ & 75 & $\begin{array}{l}\text { Persistent primary } \\
\text { sleep-maintenance } \\
\text { insomnia }\end{array}$ & $\begin{array}{l}\text { CBT, progressive muscle } \\
\text { relaxation training or a sham } \\
\text { behavioral intervention }\end{array}$ & $\begin{array}{l}\text { CBT was effective for reducing dysfunctional } \\
\text { beliefs about sleep than other treatments and } \\
\text { these changes endured throughout the follow- } \\
\text { up period. JSS } 3 \text {. }\end{array}$ \\
\hline $\begin{array}{l}\text { Lichstein et al. } \\
(2001)^{32}\end{array}$ & 89 & $\begin{array}{l}\text { Older adults with } \\
\text { insomnia }\end{array}$ & $\begin{array}{l}\text { Relaxation, sleep compression or } \\
\text { placebo desensitization }\end{array}$ & $\begin{array}{l}\text { All treatments improved self-reported sleep but } \\
\text { objective sleep was unchanged. Sleep } \\
\text { compression was most effective. JSS } 2 \text {. }\end{array}$ \\
\hline
\end{tabular}

* Waiting list: no treatment; ${ }^{\star \star}$ a westernized and simplified version of Tai Chi. 


\section{Results}

The search is summarized in Table 1. Twelve articles were identified which matched our inclusion criteria. Subjects mainly belonged to the following two categories: older adults or hypnoticdependent patients. In order to review the efficacy of mind-body interventions that were not mainstream, "sleep hygiene" and "CBT" were not terms directly searched in this review, however, they were the most frequently used forms of mind-body treatment for insomnia which matched our inclusion criteria.

Only two studies compared mind-body interventions with medication. In one of these studies, CBT showed better results than zopiclone; ${ }^{25}$ in the other study, flurazepam was superior to progressive muscle relaxation plus cognitive distraction (PMR/ $\mathrm{CD})$, sleep restriction and stimulus control (SR/SC) or sleep hygiene education. ${ }^{28}$ Most of the studies compared mind-body intervention with no treatment (waiting-list control). However, two studies showed that mind-body interventions can improve sleep quality of long-term hypnotic drug users. ${ }^{24,27}$ In one of these studies users demonstrated a reduced consumption of these drugs. ${ }^{27}$

\section{Discussion}

\section{Polysomnography (PSG)}

One aspect that must be discussed with regard to the cited articles is the way in which results were measured. Diagnosis of insomnia is based on clinical reports. We can measure the results of interventions through questionnaires or through objective findings such as PSG. In this review, three of the twelve studies (clinically controlled and randomized) used PSG to measure results of interventions. In one of the studies objective sleep was unchanged after relaxation, sleep compression or placebo desensitization, although all treatments improved subjective sleep quality. ${ }^{32}$ Nevertheless, in another study, CBT showed better sleep efficiency in PSG than in patients taking zopiclone. In the same study, the CBT group exhibited an increase in sleep stages 3 and 4 and a decrease in time awake during the PSG as compared to the zopiclone or placebo groups. ${ }^{25}$ In another study, cognitive changes were correlated with improvements noted on both objective (PSG) and subjective measures of insomnia symptoms, particularly within the CBT group..$^{31}$

\section{Questionnaires}

Other studies used questionnaires to evaluate outcomes of therapeutic interventions. Using specific questionnaires for insomnia, such as insomnia severity or the PSQI, online treatment, psychoeducation, stimulus control instruction, sleep restriction, relaxation training and classical music were all found to lead to improvements in these two measures. ${ }^{21,23}$ Subjects in the Tai chi group showed improvement in the PSQI. ${ }^{22}$

A reduction in sleep latency, an increase in sleep efficiency (calculated using questionnaire responses) and a significant reduction in the frequency of hypnotic drug use in the CBT group were observed. ${ }^{29}$ In another study, the CBT group (as compared to sleep hygiene or placebo) showed improvements in the following parameters: sleep onset, wake time after sleep onset and sleep efficiency (calculated using the PSQI). ${ }^{24}$ CBT was effective for reducing dysfunctional beliefs about sleep and changes were associated with other positive outcomes in insomnia treatment. ${ }^{31}$

Yoga led to an increase in the number of hours of sleep and in the feeling of being rested in the morning, but the waiting-list control group (no intervention) and the ayurveda (a herbal preparation) group did not show increased hours of sleep. ${ }^{26}$

A sleep diary was used to evaluate a group exposed to sleep hygiene with a stimulus control, and it was compared to that of a group exposed to sleep hygiene and a relaxation tape. The authors observed that the effects of both treatments were greater for nocturnal measures as compared to daytime measures. However, there were no differences in treatment interventions when compared one to another. ${ }^{30}$

\section{Follow-up}

One important aspect to analyze is the follow-up. In one study of maintenance insomnia, $25.8 \%$ of subjects demonstrated clinically significant improvements at the six-month follow-up in both interventions (sleep hygiene + stimulus control vs. sleep hygiene + relaxation tape). Changes from pretreatment to followup were generally significant, showing that the treatment gains were stable and long-lasting. ${ }^{30}$

In another study, the positive outcomes of CBT appeared to be robust over time, persisting for at least one year among more treatment-adherent patients. ${ }^{27}$

Patients who practised yoga for six months felt rested in the morning based on a rating scale. This was not observed in the ayurvedic herbal group or in the waiting-list group. ${ }^{26}$

\section{General comments}

According to the studies we selected, all mind-body treatments improved self-reported sleep. However, some treatments, like relaxation or sleep compression, did not lead to improvements in objective sleep. ${ }^{32}$

Considering the side effects of hypnotic drugs, especially in elderly patients, research on mind-body interventions in hypnotic drug dependents is very relevant. ${ }^{13}$ Both studies on this topic showed that these interventions can ameliorate sleep quality ${ }^{24}$ and reduce the use of hypnotic drugs. ${ }^{24-27}$ These results offer an important example of how mind-body interventions can help allopathic medicine.

A cost-effective method for treating insomnia is an online intervention that includes psychoeducation, sleep hygiene, stimulus control instruction, sleep restriction treatment, relaxation training, cognitive therapy and help with medication tapering. Online treatment produced improvements in the primary end points of sleep quality, insomnia severity and daytime fatigue. This online treatment also produced significant changes in pre-sleep cognitive arousal and dysfunctional beliefs about sleep. This is a promising modality of mind-body intervention even though the lack of an active control limited the conclusions that could be drawn from this study. ${ }^{21}$ 
Sleep hygiene is the most frequently cited intervention in these articles. It is presented along with other interventions ${ }^{21,24,25,30}$ like CBT or an active control. ${ }^{28}$ Considering that many insomniacs present "bad" habits before sleep, these instructions per se can change the quality of sleep.

CBT seems to be the most complete and effective mind-body intervention, including relaxation, other behavioral techniques and cognitive therapy. Considering that insomniac patients have difficulty falling asleep because of multiple factors (for example, intrusive thoughts, dysfunctional beliefs, anxiety, stress and physical discomfort), the components of CBT can improve at least some of these factors. CBT was the only intervention that showed better results than medication. ${ }^{25}$ Half of the studies reviewed tested the effects of CBT on insomnia. ${ }^{21-23,27,29,31}$ The other studies focused on therapies such as music, Yoga, Tai Chi Chi (a westernized and standardized version of Tai Chi, consisting of 20 simple and separate movements), relaxation and sleep hygiene.

On one hand, only five of the twelve chosen studies reached a score of 3 on the Jadad scale. That is, only five studies attained regular methodological quality. On the other hand, we must consider that it is difficult to control mind-body interventions using the same criteria as medical interventions (for example, the blindness criterion). Analyzing mind-body interventions using the same rules of methodological quality as for medical interventions can lead to the misinterpretation that mind-body intervention studies are not "good science." In some cases, researchers are doing the best science that can be done when interventions include involvement with the clients or patients. These human qualities, including empathy, beliefs, humanization of the environment and attendance are required more and more in the health care system. Another scale for evaluation must be developed to look at the methodological quality of these interventions.

\section{Conclusion}

In this review, studies presented different instruments used in the evaluation of the outcome of interventions for insomnia. Subjects were selected differently in each study. Different therapies were analyzed; in addition, the time of treatment varied from one study to another. However, some important implications for practice and for research are presented below.

\section{Implications for practice}

Collectively, mind-body therapies were able to improve sleep quality in terms of subjective and/or objective findings. Among these studies, the more methodologically sound studies showed that CBT could improve insomnia symptoms. CBT seems to be the most complete and effective mind-body intervention, and was the only intervention that showed better results than medication. Only a few studies about mind-body interventions that are not mainstream (CBT or sleep hygiene) reached the inclusion criteria for this study. Among them yoga, tai chi chih, relaxation and music presented positive results in the treatment of insomnia symptoms. Research into practices that belong to CAM generally presented lack of adequate randomization or control and could not be included in this review.

\section{Implications for research}

Considering that only five of the twelve studies chosen reached a score of 3 on the Jadad scale, researchers in the mind-body field should discuss the best methodological control that can be attained in these studies. In the future, more precise methodological scales to evaluate the quality standards of these interventions should be developed. 
Disclosures

\begin{tabular}{|c|c|c|c|c|c|c|c|}
\hline $\begin{array}{c}\text { Writing group } \\
\text { member }\end{array}$ & Employment & $\begin{array}{l}\text { Research } \\
\text { grant }^{1}\end{array}$ & $\begin{array}{l}\text { Other research grant or } \\
\text { medical continuous } \\
\text { education }\end{array}$ & $\begin{array}{l}\text { Speaker's } \\
\text { honoraria }\end{array}$ & $\begin{array}{l}\text { Ownership } \\
\text { interest }\end{array}$ & $\begin{array}{l}\text { Consultant/ } \\
\text { Advisory } \\
\text { board }\end{array}$ & Other ${ }^{3}$ \\
\hline $\begin{array}{l}\text { Elisa Harumi } \\
\text { Kozasa }\end{array}$ & $\begin{array}{l}\text { Universidade } \\
\text { Nove de Julho }\end{array}$ & $\begin{array}{l}\text { CNPq } \\
\text { IEEPAA }\end{array}$ & - & - & - & - & - \\
\hline Helena Hachul & $\begin{array}{l}\text { UNIFESP } \\
\text { Hospital Santa } \\
\text { Marcelina }\end{array}$ & - & - & - & - & - & - \\
\hline Carlos Monson & $\begin{array}{c}\text { Centro Cochrane } \\
\text { do Brasil }\end{array}$ & - & - & - & - & - & - \\
\hline Luciano Pinto Jr. & Instituto do Sono & - & - & - & - & - & - \\
\hline $\begin{array}{l}\text { Marcelo Csermak } \\
\text { Garcia }\end{array}$ & UNIFESP & - & - & - & - & - & - \\
\hline $\begin{array}{l}\text { Luiz Eugênio de } \\
\text { Araújo Moraes } \\
\text { Mello }\end{array}$ & UNIFESP & FAPESP & - & - & - & - & - \\
\hline Sérgio Tufik & UNIFESP & $\begin{array}{l}\text { FAPESP } \\
\text { CNPq }\end{array}$ & - & - & - & - & - \\
\hline
\end{tabular}

${ }^{*}$ Modest

** Significant

*** Significant: Amounts given to the author's institution or to a colleague for research in which the author has participation, not directly to the author.

Note: UNIFESP = Universidade Federal de São Paulo; CNPq = Conselho Nacional de Desenvolvimento Cientifico e Tecnológico; IEEPAA = Instituto Israelita de Ensino e Pesquisa Albert Einstein; FAPESP = Fundação de Apoio à Pesquisa do Estado de São Paulo.

For more information, see Instructions for Authors.

References

1. Ohayon MM. Prevalence of DSM-IV diagnostic criteria of insomnia: distinguishing insomnia related to mental disorders from sleep disorders. J Psychiatr Res. 1997;31(3):333-46.

2. Ohayon MM, Caulet M, Priest RG, Guilleminault C. DSM-IV and ICSD90 insomnia symptoms and sleep dissatisfaction. Br J Psychiatry. 1997;171:382-8.

3. Breslau N, Roth T, Rosenthal L, Andreski P. Sleep disturbance and psychiatric disorders: a longitudinal epidemiological study of young adults. Biol Psychiatry. 1996;39(6):411-8.

4. Ford DE, Kamerow DB. Epidemiologic study of sleep disturbances and psychiatric disorders. An opportunity for prevention? JAMA. 1989;262(11):1479-84.

5. Leger D, Guilleminault C, Dreyfus JP, Delahaye C, Paillard M. Prevalence of insomnia in a survey of 12,778 adults in France. J Sleep Res. 2000;9(1):35-42.

6. American Psychiatric Association - APA. Diagnostic and statistical manual of mental disorders, 4th ed. DSM-IV. Washington: APA; 1994.

7. Morin CM, LeBlanc M, Daley M, Gregoire JP, Mérette C. Epidemiology of insomnia: prevalence, self-help treatments, consultations, and determinants of help-seeking behaviors. Sleep Med. 2006;7(2):123-30.

8. LeBlanc M, Beaulieu-Bonneau S, Mérette C, Savard J, Ivers H, Morin CM. Psychological and health-related quality of life factors associated with insomnia in a population-based sample. J Psychosom Res. 2007;63(2):157-66.

9. Taylor DJ, Lichstein KL, Durrence HH, Reidel BW, Bush AJ. Epidemiology of insomnia, depression, and anxiety. Sleep. 2005;28(11):1457-64.

10. Gallup Organization. Sleep in America: 1995. Princeton, NJ: Gallup; 1995.

11. Mellinger GD, Balter MB, Uhlenhuth EH. Insomnia and its treatment. Prevalence and correlates. Arch Gen Psychiatry. 1985;42(3):225-32.

12. Neutel CI, Patten SB. Sleep medication use in Canadian seniors. Can J Clin Pharmacol. 2009;16(3):e443-52.

13. Hollingworth SA, Siskind DJ. Anxiolytic, hypnotic and sedative medication use in Australia. Pharmacoepidemiol Drug Saf. 2010;19(3):280-8.

14. Nowell PD, Mazumdar S, Buysse DJ, Dew MA, Reynolds CF III, Kupfer DJ. Benzodiazepines and zolpidem for chronic insomnia: A meta-analysis of treatment efficacy. JAMA. 1997;278(24):2170-7.

15. Barnes PM, Bloom B, Nahin R. Complementary and Alternative Medicine Use Among Adults and Children: United States, 2007. CDC National Health Statistics Report 12. 2008 Dec 10.
16. National Center of Complementary and Alternative Medicine. CAM basics. Online document. [cited 2010 Feb 23]. Available from:http://nccam. nih.gov/health/whatiscam/D347.pdf/

17. Jacobs GD. Clinical applications of the relaxation response and mind-body interventions. J Altern Complement Med. 2001;7 Suppl 1:S93-101.

18. Morin CM, Colecchi C, Stone J, Sood R, Brink D. Behavioral and pharmacological therapies for late-life insomnia: A randomized controlled trial. JAMA. 1999;281(11):991-9.

19. Morin CM. Combined therapeutics for insomnia: should our first approach be behavioral or pharmacological? Sleep Med. 2006;7 Suppl 1:S15-9.

20. Jadad AR, Moore RA, Carrol D, Jenkinson C, Reynolds JM, Gavahan DJ, Mc Quay HJ. Assessing the quality of reports of randomized clinical trilas: is blinding necessary? Control Clin Trials. 1996;17(1):1-12.

21. Vincent N, Lewycky S. Logging on for better sleep RCT of the effectiveness of online treatment for sleep. Sleep. 2009;32(6):807-15.

22. Irwin MR, Olmstead R, Motivala SJ. Improving sleep quality in older adults with moderate sleep complaints: a randomized controlled trial of Tai Chi Chih. Sleep. 2008;31(7):1001-8.

23. Harmat L, Takács J, Bódizs R. Music improves sleep quality in students. J Adv Nurs. 2008;2(3):327-35.

24. Soeffing JP, Lichstein KL, Nau SD, McCrae CS, Wilson NM, Aguillard RN, Lester KW, Bush AJ. Psychological treatment of insomnia in hypnoticdependant older adults. Sleep Med. 2008;9(2):165-71.

25. Sivertsen B, Omvik S, Pallesen S, Bjorvatn B, Havik OE, Kvale G, Nielsen GH, Nordhus IH. Cognitive behavioral therapy vs zopiclone for treatment of chronic primary insomnia in older adults: a randomized controlled trial. JAMA. 2006;295(24):2851-58.

26. Manjunath NK, Telles $S$. Influence of Yoga \& Ayurveda on self-rated sleep in a geriatric population. Indian J Med Res. 2005;121(5):683-90.

27. Morgan K, Dixon S, Mathers N, Thompson J, Tomeny M. Psychological treatment for insomnia in the regulation of long-term hypnotic drug use. Health Technol Assess. 2004;8(8)iii-iv, 1-68.

28. Waters WF, Hurry MJ, Binks PG, Carney CE, Lajos LE, Fuller KH, Betz B, Johnson J, Anderson T, Tucci JM. Behavioral and hypnotic treatments for insomnia subtypes. Behav Sleep Med. 2003;1(2):81-101.

29. Morgan K, Dixon S, Mathers N, Thompson J, Tomeny M. Psychological treatment for insomnia in the management of long-term hypnotic 
Kozasa EH et al.

drug use: a pragmatic randomised controlled trial. $\mathrm{Br} J$ Gen Pract. 2003;53(497):923-8.

30. Pallesen S, Nordhus IH, Kvale G, Nielsen GH, Havik OE, Johnsen BH, Skjotskift S. Behavioral treatment of insomnia in older adults: an open clinical trial comparing two interventions. Behav Res Ther. 2003; 41(1):31-48.

31. Edinger JD, Wohlgemuth WK, Radtke RA, Marsh GR, Quillian RE. Does cognitive-behavioral insomnia therapy alter dysfunctional beliefs about sleep? Sleep. 2001;24(5):591-9.

32. Lichstein KL, Riedel BW, Wilson NM. Relaxation and Sleep Compression for Late- Life Insomnia: A Placebo-Controlled Trial. J Consult Clin Psychol. 2001;69(2):227-39. 